\title{
Antioxidant strategies for Alzheimer's disease
}

\author{
Michael Grundman* and Patrick Delaney \\ Alzheimer's Disease Cooperative Study, University of California, San Diego, 8950 Villa La Jolla Drive, Suite 2200, \\ La Jolla, California 92037, USA
}

\begin{abstract}
Oxidative damage is present within the brains of patients with Alzheimer's disease (AD), and is observed within every class of biomolecule, including nucleic acids, proteins, lipids and carbohydrates. Oxidative injury may develop secondary to excessive oxidative stress resulting from $\beta$-amyloid-induced free radicals, mitochondrial abnormalities, inadequate energy supply, inflammation or altered antioxidant defences. Treatment with antioxidants is a promising approach for slowing disease progression to the extent that oxidative damage may be responsible for the cognitive and functional decline observed in $\mathrm{AD}$. Although not a uniformly consistent observation, a number of epidemiological studies have found a link between antioxidant intake and a reduced incidence of dementia, $\mathrm{AD}$ and cognitive decline in elderly populations. In $\mathrm{AD}$ clinical trials molecules with antioxidant properties such as vitamin E and Ginkgo biloba extract have shown modest benefit. A clinical trial with vitamin $E$ is currently ongoing to determine if it can delay progression to $\mathrm{AD}$ in individuals with mild cognitive impairment. Combinations of antioxidants might be of even greater potential benefit for $\mathrm{AD}$, especially if the agents worked in different cellular compartments or had complementary activity (e.g. vitamins $\mathrm{E}, \mathrm{C}$ and ubiquinone). Naturally-occurring compounds with antioxidant capacity are available and widely marketed (e.g. vitamin C, ubiquinone, lipoic acid, $\beta$-carotene, creatine, melatonin, curcumin) and synthetic compounds are under development by industry. Nevertheless, the clinical value of these agents for $\mathrm{AD}$ prevention and treatment is ambiguous, and will remain so until properly designed human trials have been performed.
\end{abstract}

Alzheimer's disease: Oxidative stress: Antioxidants: Vitamins: Dietary supplements

A large number of studies indicate that oxidative injury is present in the brains of patients with Alzheimer's disease (AD) and may play a role in the development of AD (Pratico \& Delanty, 2000; Rottkamp et al. 2000; Smith et al. 2000). Oxidative damage has been found in all classes of organic molecules that are critical for maintaining neuronal structural and functional integrity. Excessive lipid peroxidation (e.g. malondialdehyde, 4-hydroxynonenal, isoprostanes), protein oxidation (e.g. protein carbonyls, nitrotyrosine, dityrosine etc.), DNA oxidation (DNA strand breaks, base modification) and glyco-oxidation (e.g. advanced glycation endproducts) have all been documented in the brain in AD.

Studies have demonstrated an increase in oxidized lipids using a variety of methods. Malondialdehyde and 4-hydroxynonenal are products of lipid peroxidation. Studies indicate both increased malondialdehyde concentrations in the brain in AD (Lovell et al. 1995; Marcus et al.
1998), as well as 4-hydroxynonenal protein adducts in neurofibrillary tangles (Markesbery \& Lovell, 1998). F-2 isoprostanes (isomers of prostaglandins derived from free radical oxidation of polyunsaturated fatty acids) are elevated in plasma, urine and cerebrospinal fluid (CSF) of patients with $\mathrm{AD}$ (Pratico et al. 2000). F-4 isoprostanes, derived from free radical oxidation of docosahexaenoic acid (DHA) are also increased in AD (Nourooz-Zadeh et al. 1999).

Protein carbonyls, a measure of protein oxidation, are present in both tangle- and non-tangle-bearing neurons of brains in AD (Smith et al. 1996). Nitrotyrosine is similarly found in neurons of patients with $\mathrm{AD}$, suggesting peroxynitrite-mediated protein damage (Good et al. 1996; Smith et al. 1997). Oxidative injury to DNA is suggested by elevated levels of DNA strand breaks and oxidized bases. Brain samples from patients with AD show approximately a twofold higher number of DNA strand breaks than those of controls (Mullaart et al. 1990).

Abbreviations: AD, Alzheimer's disease; CSF, cerebrospinal fluid; DHA, docosahexaenoic acid

*Corresponding author: Dr Michael Grundman, fax +1 858452 3058, email mgrundman@ucsd.edu 
Hydroxyl radical attack on deoxyguanosine is indicated by a threefold increase in 8-hydroxy-2-deoxyguanosine in mitochondrial DNA from brain samples from patients with $\mathrm{AD}$ (Mecocci et al. 1994). In AD hippocampal neurons demonstrate intense cytoplasmic staining with 8-hydroxy2-deoxyguanosine antibodies (Nunomura et al. 1999). 8-Hydroxy-2-deoxyguanosine is increased in the ventricular CSF from patients with AD (Lovell et al. 1999a).

Oxidative processing of monosaccharides can result in the formation of abnormal glycosylated proteins (advanced glycation endproducts). Plaque fractions of brains from patients with $\mathrm{AD}$ contain a threefold increase in advanced glycation endproduct adducts compared with controls (Vitek et al. 1994). Advanced glycation endproducts are also increased in neurofibrillary tangles and neuritic plaques, suggesting a close link between abnormal oxidation of monosaccharides, glycosylation of proteins and fundamental AD pathology (Guevara et al. 1998; Yan et al. 1994).

Oxidative stress in $\mathrm{AD}$ may result from aging, energy deficiency, inflammation or excessive production of $\beta$-amyloid. $\beta$-Amyloid, present in amyloid plaques, can induce cell death through a mechanism involving $\mathrm{H}_{2} \mathrm{O}_{2}$ (Behl et al. 1994). Overproduction or impaired clearance of $\beta$-amyloid is believed by many researchers to be a critical step in the development of AD. Interestingly, oxidative stress also induces the expression and misprocessing of amyloid precursor protein leading to the generation of amyloidogenic fragments (Gabuzda et al. 1994; Misonou et al. 2000). This process can result in a potentially vicious cycle whereby oxidative stress leads to $\beta$-amyloid and $\beta$-amyloid, in turn, leads to more oxidative stress, neuronal dysfunction and ultimately neuronal death.

A variety of compounds and antioxidants have been suggested for reducing the oxidative stress associated with $\mathrm{AD}$ (Table 1). Many of these agents have been shown to protect cells from $\beta$-amyloid-induced neurotoxicity. Table 2 summarizes studies that have compared antioxidant concentrations in $\mathrm{AD}$ patients and controls. A number of studies suggest that antioxidant concentrations in the plasma, CSF and brains of $\mathrm{AD}$ patients may be altered. It is not clear, however, whether these changes contribute to or exacerbate

Table 1. Some agents with antioxidant properties proposed for prevention or treatment of Alzheimer's disease

\begin{tabular}{|c|c|}
\hline Agent & References \\
\hline Vitamin $\mathrm{E}^{*}$ & Behl et al. (1992), Zhou et al. (1996), Subramaniam et al. (1998), Pereira et al. (1999), Yatin et al. (1999) \\
\hline Vitamin $C^{*}$ & Behl et al. (1994), Yallampalli et al. (1998) \\
\hline Vitamin A & Jama et al. (1996), Perrig et al. (1997) \\
\hline Ubiquinone & Beal \& Matthews (1997) \\
\hline Idebenone* & Hirai et al. (1998), Pereira et al. (1999) \\
\hline Creatine $^{\star}$ & Brewer \& Wallimann (2000) \\
\hline Lipoic acid & Packer et al. (1997), Hager et al. (2001) \\
\hline Cholesterol $^{*}$ & Zhou \& Richardson (1996) \\
\hline Docosahexaenoic acid & Hossain et al. (1999), Jeyarajah et al. (1999) \\
\hline $\mathrm{Zn}^{*}$ & Lovell et al. (1999b), Huang et al. (2000), Moreira et al. (2000) \\
\hline $\mathrm{Li}^{*}$ & Wei et al. (2000) \\
\hline $\mathrm{Se}^{*}$ & Jimenez-Jimenez et al. (1996) \\
\hline Ginkgo biloba extract ${ }^{\star}$ & Bastianetto et al. (1999), Yao et al. (2001) \\
\hline Ginseng & Kim et al. (1998) \\
\hline Acetylcarnitine ${ }^{*}$ & Behl et al. (1994) \\
\hline Melatonin* & Pappolla et al. (1997), Daniels et al. (1998), Bachurin et al. (1999) \\
\hline Indole-3-proprionic acid* & Chyan et al. (1999) \\
\hline Curcumin* & Kim et al. (2001) \\
\hline Resveratrol & Roth et al. (1999) \\
\hline Quercetin & Roth et al. (1999) \\
\hline Vinpocetine & Pereira et al. (2000) \\
\hline Ferulic acid & Yan et al. (2001) \\
\hline Pycnonegenol & Liu et al. (2000) \\
\hline Garlic extract, aged & Borek (2001) \\
\hline Deferoxamine & Rottkamp et al. (2001) \\
\hline Tacrine* $^{*}$ & Fagarasan \& Efthimiopoulos (1996), Svensson \& Nordberg (1998) \\
\hline Donepezil ${ }^{*}$ & Svensson \& Nordberg (1998) \\
\hline Huperzine $A^{\star}$ & Xiao et al. (2000a) \\
\hline Nicotine $^{*}$ & Kihara et al. (1997) \\
\hline Flupirtine $^{*}$ & Muller et al. (1997) \\
\hline Indomethacin* & Fagarasan \& Aisen (1996) \\
\hline Glutathiamine ethyl ester* & Pereira et al. (1999) \\
\hline$N$-acetylcysteine ${ }^{\star}$ & Olivieri et al. (2001) \\
\hline$\beta-F G F^{\star}$ & Mark et al. (1997) \\
\hline Oestrogen ${ }^{\star}$ & Behl et al. (1997) \\
\hline Kaempferol* & Roth et al. (1999) \\
\hline
\end{tabular}

$\beta$-FGF, $\beta$-fibroblast growth factor.

${ }^{*}$ Agents shown to be protective against $\beta$-amyloid toxicity. 
Table 2. Case-control studies examining antioxidant concentrations in patients with Alzheimer's disease (AD) and controls

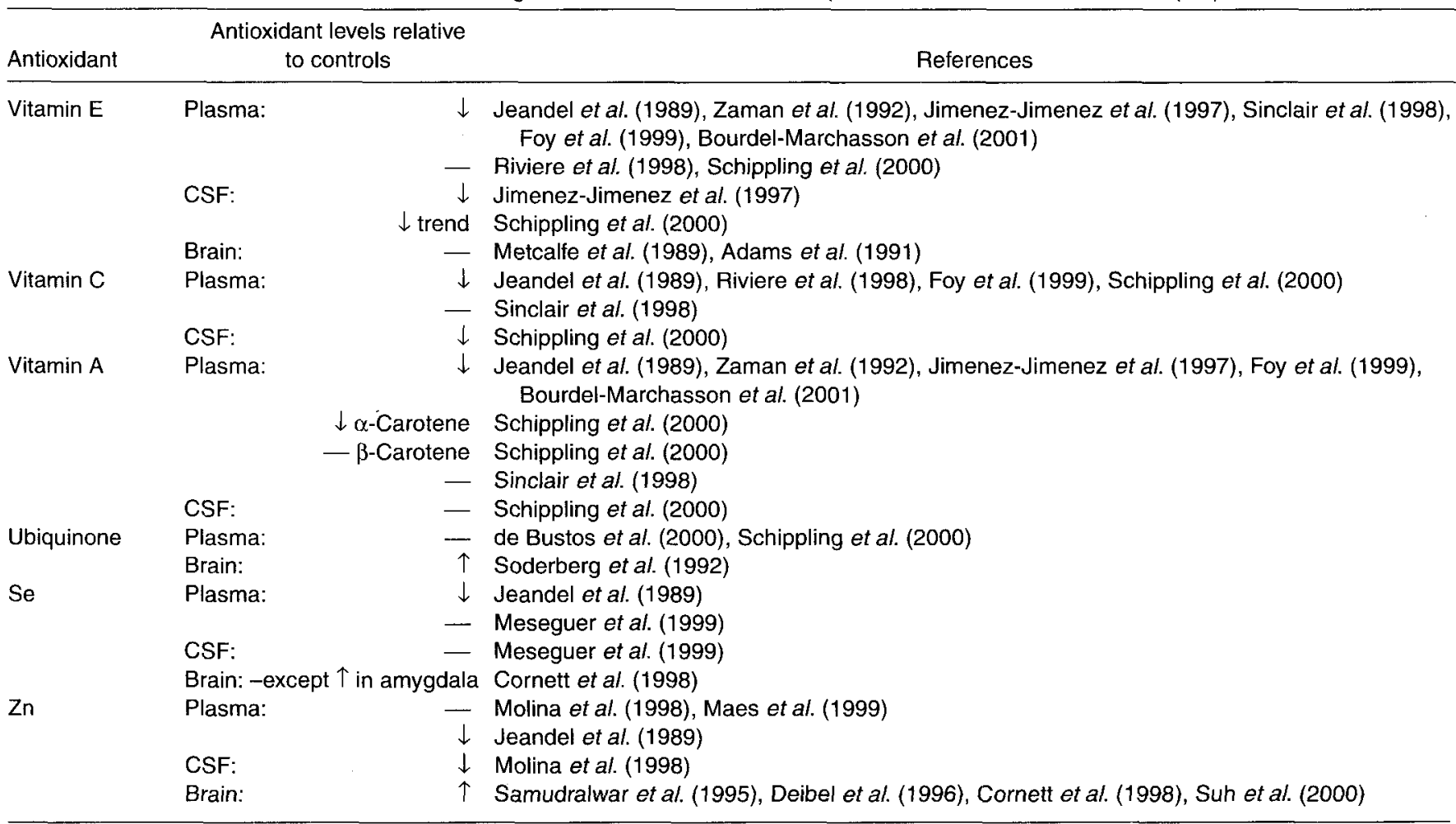

CSF, cerebrospinal fluid; $(\downarrow)$, reduced; $(\uparrow)$, increased; $(-)$, no change.

Table 3. Association of antioxidants with Alzheimer's disease (AD) or cognitive impairment (Cl) in community studies

\begin{tabular}{|c|c|c|c|}
\hline \multirow{2}{*}{$\frac{\text { Antioxidant }}{\text { Vitamin } E}$} & \multicolumn{2}{|c|}{$\begin{array}{l}\text { Association between higher } \\
\text { intake or serum concentration of } \\
\text { antioxidant and risk of } \mathrm{AD} \text { or } \mathrm{Cl}\end{array}$} & References \\
\hline & AD: & $\underline{\downarrow}$ & $\begin{array}{l}\text { Morris et al. (1998), Engelhart et al. (2000) } \\
\text { Masaki et al. (2000) }\end{array}$ \\
\hline & $\mathrm{Cl}:$ & $\downarrow$ & $\begin{array}{l}\text { La Rue et al. (1997), Schmidt et al. (1998), Perkins et al. (1999), Masaki et al. (2000), } \\
\text { Morris et al. (2000) }\end{array}$ \\
\hline & & - & Jama et al. (1996), Perrig et al. (1997) \\
\hline Vitamin C & AD: & $\stackrel{\downarrow}{-}$ & $\begin{array}{l}\text { Morris et al. (1998), Engelhart et al. (2000) } \\
\text { Masaki et al. (2000) }\end{array}$ \\
\hline & $\mathrm{Cl}$ & $\stackrel{\downarrow}{-}$ & $\begin{array}{l}\text { La Rue et al. (1997), Perrig et al. (1997), Paleologos et al. (1998), Masaki et al. (2000) } \\
\text { Jama et al. (1996), Schmidt et al. (1998), Perkins et al. (1999), Morris et al. (2000) }\end{array}$ \\
\hline Vitamin A & $\begin{array}{l}\mathrm{AD}: \\
\mathrm{Cl}\end{array}$ & - & $\begin{array}{l}\text { Engelhart et al. (2000) } \\
\text { Jama et al. (1996), La Rue et al. (1997), Perrig et al. (1997), Schmidt et al. (1998) } \\
\text { Perkins et al. (1999) }\end{array}$ \\
\hline Se & $\begin{array}{l}\mathrm{AD}: \\
\mathrm{Cl}:\end{array}$ & - & $\begin{array}{l}\text { Engelhart et al. (2000) } \\
\text { Perkins et al. (1999) } \\
\text { Berr et al. (2000) }\end{array}$ \\
\hline Red wine & $\mathrm{Cl}:$ & $\downarrow$ & Orgogozo et al. (1997) \\
\hline
\end{tabular}

( $)$, Reduced risk; (-), no association.

AD, or are simply epiphenomenona with only minimal, if any, impact on the rate of cognitive and functional decline. Table 3 summarizes reports that have evaluated the relationship between antioxidants and the development of $\mathrm{AD}$ or cognitive impairment in community studies. There have been very few randomized double-blind clinical trials evaluating antioxidants for AD. Most of our knowledge to date relies on epidemiological studies. In these investigations antioxidant intake is non-random and determined by the individual subject based on their own dietary preferences, thereby making it difficult to generalize results to other subjects. The following discussion highlights those dietary antioxidants that have been most frequently studied. 


\section{Antioxidant vitamins and minerals}

\section{Vitamin $E$}

Vitamin $\mathrm{E}$ is a lipid-soluble (membrane) antioxidant. There are several postulated mechanisms for $\alpha$-tocopherol to exert such an effect, including protection of neurons from $\beta$-amyloid protein toxicity (Behl et al. 1992), trapping of free radicals and inhibition of lipid peroxidation.

There is a reasonable amount of evidence that vitamin $\mathrm{E}$ metabolism is altered in patients with AD. Jeandel et al. (1989) found that serum vitamin $\mathrm{E}$ concentrations were decreased compared with normal controls. This finding is consistent with more recent findings by other investigators (Zaman et al. 1992; Jimenez-Jimenez et al. 1997; Sinclair et al. 1998; Foy et al. 1999; Bourdel-Marchasson et al. 2001). However, Riviere et al. (1998) did not detect a significant difference in plasma vitamin $\mathrm{E}$ concentrations between normal controls and patients with AD. JimenezJimenez et al. (1997) found lower vitamin E concentrations in the CSF of patients with AD and Schippling et al. (2000) found a similar trend. Metcalfe et al. (1989) found no difference in cerebral tocopherol concentrations between patients with $\mathrm{AD}$ and controls. Adams et al. (1991) also observed no differences in vitamin $E$ concentrations in most brain regions, but found an increased concentration of vitamin $E$ in the midbrain of patients with $A D$.

In cross-sectional data from The Austrian Stroke Prevention Study (Schmidt et al. 1998) cognitive performance, as measured by the Mattis Dementia Rating Scale, was compared with plasma levels of serum antioxidants. Only $\alpha$-tocopherol remained associated with cognitive function after linear regression analysis for possible confounders. Decreasing serum concentrations of vitamin $\mathrm{E}$ per unit cholesterol were also associated with lower memory performance in a large multi-ethnic elderly sample in the USA (Perkins et al. 1999).

Vitamin $E$ supplementation has also been asserted to exert effects specific to AD. A recent report from the Rotterdam Study (Engelhart et al. 2000) found that high dietary intake of vitamin $\mathrm{E}$ decreased the risk of subsequent development of AD. Conversely, a study reported by Masaki et al. (2000) did not find a protective effect of vitamin $\mathrm{E}$ on the development of $\mathrm{AD}$, although use of vitamin $\mathrm{E}$ or $\mathrm{C}$ was associated with less cognitive decline. In a study published by Morris et al. (1998) a group of 633 disease-free patients older than 65 years was followed prospectively, with vitamin users identified at entry. None of the subgroup using vitamin $E$ ( $n$ 27) developed AD at the time of follow-up, whereas it was predicted that 3.9 patients in the subgroup would have developed AD.

A 1997 report from the Alzheimer's Disease Cooperative Study (Sano et al. 1997b) demonstrated approximately an 8-month delay to substantial worsening (death, institutionalization, loss of activities of daily living, decline in clinical dementia scale from 2 to 3 ) in patients with moderately-severe AD. This group had a lower rate of institutionalization over 2 years than did a placebo group ( $39 \%$ v. $26 \%$ ). Unfortunately, the study did not demonstrate a difference in cognitive testing between the treated and untreated groups, possibly due to the relatively advanced stage of the patients in the study.
Presently underway is the Memory Impairment Study (Grundman, 2000), in which patients with memory impairment who don't yet have a diagnosis of AD, but are defined as having mild cognitive impairment, have been recruited at approximately seventy-five centres across North America. There are three arms in the trial, including vitamin $\mathrm{E}$, donepezil and placebo. The goal of the trial is to determine whether vitamin $\mathrm{E}$ or donepezil can delay the onset of a clinical diagnosis of AD. The dose of vitamin $\mathrm{E}$ that is being administered is $2000 \mathrm{IU} / \mathrm{d}$, which is the same dose as that used in the previous vitamin E clinical trial (Sano et al. 1997b).

\section{Vitamin C}

Vitamin C is a water-soluble (cytoplasmic) antioxidant. Jeandel et al. (1989) reported a decrease in vitamin C concentrations in the plasma of patients with AD compared with normal controls. Similarly, Riviere et al. (1998) and Foy et al. (1999) observed lower plasma vitamin C levels in subjects with AD. Schippling et al. (2000) found that ascorbate levels were lower in both the plasma and CSF of patients with $\mathrm{AD} v$. non-demented controls. In contrast, Sinclair et al. (1998) did not find a significant difference in plasma vitamin $C$ concentrations between patients with $A D$ and controls.

A report from the Rotterdam Study (Engelhart et al. 2000) found that high dietary intake of vitamin $C$ decreased the subsequent risk of AD. Masaki et al. (2000) reported no benefit of vitamin $\mathrm{C}$ on the development of $\mathrm{AD}$. Morris et al. (1998) prospectively followed an AD-free population sample $>65$ years of age, in whom vitamin users were identified at intake. At follow-up ( 4.3 years), ninety-one of 633 subjects had developed AD. None of the twenty-three vitamin $C$ users developed $A D$, whereas it was predicted that $3 \cdot 3$ subjects would develop it. Paleologos et al. (1998) reported on a cohort study of 117 subjects recruited from a retirement community. Vitamin $\mathrm{C}$ intake was assessed at baseline, and cognitive testing was performed 4 years later. Consumption of vitamin $\mathrm{C}$ supplements was associated with a lower prevalence of cognitive impairment. Perrig et al. (1997) found that among 442 subjects aged 65-94 years, a higher plasma concentration of vitamin $C$ was associated with better memory performance.

\section{Vitamin A}

Vitamin A (retinol) is a lipid-soluble antioxidant derived from more complex carotenoids in the diet. Jeandel et al. (1989) found that serum vitamin A concentrations were decreased in patients with AD. Similarly, other researchers have reported lower serum vitamin $A$ concentrations in patients with AD (Zaman et al. 1992; Jimenez-Jimenez et al. 1997; Foy et al. 1999; Bourdel-Marchasson et al. 2001). Schippling et al. (2000) reported lower plasma $\alpha$-carotene levels but normal $\beta$-carotene concentrations. Sinclair et al. (1998) found no difference in plasma $\beta$-carotene concentrations between patients with AD and controls.

A well-executed prospective study of the effects of vitamin A supplementation for $\mathrm{AD}$ has yet to be performed. Perrig et al. (1997) found that among 442 
subjects aged 65-94 years a higher plasma concentration of $\beta$-carotene was associated with better memory performance. In a cross-sectional study from The Netherlands, Jama $e t$ al. (1996) found that a higher intake of $\beta$-carotene was associated with better cognitive performance. Similarly, Schmidt et al. (1998) found that individuals with higher plasma levels of $\beta$-carotene had better cognitive performance, although this association only showed a trend toward significance after adjusting for other variables. Other epidemiological studies have failed to find an association between cognitive performance and vitamin A (Schmidt et al. 1998; Perkins et al. 1999; Engelhart et al. 2000).

\section{Selenium}

Se has been suggested as a dietary supplement in AD, owing to its role in the reduction of oxidative stress, particularly the detoxification of peroxides. Clinical studies, however, have failed to reveal a clear relationship between Se and AD or cognitive impairment. A report from the Rotterdam study (Engelhart et al. 2000) found no correlation between Se intake and the subsequent development of AD. Perkins et al. (1999) compared serum antioxidant levels with cognitive performance in a multi-ethnic study of 4809 elderly Americans. They found no association between Se concentrations and memory performance. In contrast, Berr et al. (2000) reported that low serum Se levels were associated with an increased risk of cognitive decline in an elderly cohort after 4 years.

Other recent studies have further failed to discern a deficiency of Se as contributing to AD. Meseguer et al. (1999) studied serum and CSF levels in both AD subjects ( $n$ 27) and matched controls (n 34). No significant differences between the two groups were identified. Cornett et al. (1998) found that Se levels were comparable in brains from patients with $\mathrm{AD}$ and controls, except for a small elevation in the amygdala.

\section{Zinc}

Using histochemical methods to study the brains of subjects with $\mathrm{AD}$, Suh et al. (2000) found vivid $\mathrm{Zn}$ staining in the amyloid deposits of dense-core (senile) plaques, in the amyloid angiopathy surrounding diseased blood vessels, and in the somata and dendrites of neurons showing characteristic neurofibrillary tangles. Since brains from age-matched non-demented controls revealed only scattered neuronal staining for $\mathrm{Zn}$, the authors postulated abnormal $\mathrm{Zn}$ metabolism in $\mathrm{AD}$. Corroborative findings were reported by Cornett et al. (1998). They detected statistically significant elevations in $\mathrm{Zn}$ in multiple areas of brains from patients with AD compared with controls. Deibel et al. (1996) reported elevated levels of $\mathrm{Zn}$ in the hippocampus and amygdala of patients with AD. Molina et al. (1998) found that CSF $\mathrm{Zn}$ concentrations were decreased in patients with $A D$, with no significant difference in serum $\mathrm{Zn}$ concentrations. The latter finding was confirmed by Maes et al. (1999). Additionally, Gonzalez et al. (1999) found an association between higher serum $\mathrm{Zn}$ concentrations in patients with $\mathrm{AD}$ and the apolipoprotein E4 allele.
Against this background Lovell et al. (1999b) performed a study assessing the effect of varying $\mathrm{Zn}$ concentrations on $\beta$-amyloid toxicity in cultured hippocampal neurons. The data obtained suggest protection against $\beta$-amyloid toxicity with low $\mathrm{Zn}$ concentrations, but enhanced toxicity at higher $\mathrm{Zn}$ concentrations. This finding is in agreement with earlier reports suggesting increased aggregation of $\beta$-amyloid at high concentrations of $\mathrm{Zn}$ (Bush et al. 1994). It appears that $\mathrm{Zn}$ could be either potentially harmful or beneficial for AD. Supplementation beyond the recommended dietary allowance is probably not advisable until its role is more thoroughly studied and understood.

\section{Antioxidant dietary supplements and herbs}

\section{Ubiquinone}

Ubiquinone is an essential cofactor of the electron transport chain in mitochondria and a lipid-soluble antioxidant (Beal \& Matthews, 1997). Soderberg et al. (1992) reported increased concentrations of ubiquinone in brain tissue from subjects with AD. A recent study by de Bustos et al. (2000) found no significant difference in plasma ubiquinone concentrations between patients with AD and controls. Schippling et al. (2000) similarly found no alteration in ubiquinone concentration in plasma from patients with $\mathrm{AD}$. No large clinical studies assessing the cognitive effect of oral supplementation of ubiquinone in $\mathrm{AD}$ have been performed.

\section{otLipoic acid}

$\alpha$-Lipoic acid is a disulfide compound that serves as the coenzyme for mitochondrial $\alpha$-keto acid dehydrogenases. It is a powerful antioxidant and can recycle other antioxidants such as vitamin C, vitamin $\mathrm{E}$ and glutathione (Packer et al. 1997). In a recent open clinical trial by Hager et al. (2001) $600 \mathrm{mg} \alpha$-lipoic acid was given daily to nine patients with $\mathrm{AD}$ and related dementias for an average of $337 \mathrm{~d}$. Cognitive measures remained stable over this time period. Although the study was small and not randomized, the findings suggest that further studies with $\alpha$-lipoic acid might be worthwhile.

\section{Acetyl-L-carnitine}

Acetyl-L-carnitine is an esterified form of L-carnitine. Its function is to transfer long-chain fatty acids from the cytoplasm to the mitochondria, facilitating neuronal energy production. Clinical trials of acetylcarnitine have been disappointing. A 1996 study followed 431 AD subjects given $1 \mathrm{~g}$ acetylcarnitine three times daily for 12 months. Using standard cognitive measures for such trials the researchers found no significant differences between the treatment and placebo groups (Thal et al. 1996). A trend towards slower decline in the younger patients was noted, and Brooks et al. (1998) discussed this possibility further. Subsequently, however, Thal et al. (2000) published a trial of acetylcarnitine in early-onset AD. Again, there was no significant difference in rate of cognitive decline between the active and placebo treatment groups. Overall, there is no 
compelling evidence to recommend acetylcarnitine for treatment of $\mathrm{AD}$ at the present time.

\section{Creatine}

Creatine is a guanidino compound produced endogenously and found in meat products. Creatine and phosphocreatine provide a temporal energy buffer in times of high energy demand and a spatial energy buffer between the cytosol and mitochondria (Tarnopolsky \& Beal, 2001). Creatine probably functions as an antioxidant by enhancing energy transduction. Brewer \& Wallimann (2000) demonstrated that $\beta$-amyloid and glutamate toxicity to rat hippocampal neurons is ameliorated by creatine. The creatine buffer system may play a role in compensating for impaired energy metabolism in AD. Using magnetic resonance spectroscopy Pfefferbaum et al. (1999) found that among AD subjects higher grey-matter creatine plus phosphocreatine concentrations correlated with poorer performance on recognition memory tests. Oral loading can increase brain creatine. A study by Dechent et al. (1999) demonstrated that excess oral intake of creatine monohydrate increased brain levels of creatine over a period of several weeks. At the present time there are no reports of creatine treatment for AD.

\section{Docosahexaenoic acid}

DHA is a polyunsaturated fatty acid found in brain phospholipids. It is reported to have antioxidant properties, inhibiting NO production and enhancing cellular antioxidant enzyme activity (Hossain et al. 1999; Jeyarajah et al. 1999). An autopsy study published in 1991 (Soderberg et al. 1991) found that DHA concentrations were decreased in the brains of patients with $\mathrm{AD}$ compared with normal controls. A more recent study reported reduced concentrations of DHA in the hippocampus of patients with AD (Prasad et al. 1998). Schippling et al. (2000) reported lower concentrations of polyunsaturated fatty acids in the CSF of patients with $\mathrm{AD}$.

There have been a number of interesting epidemiological studies relating to DHA. A Rotterdam study (Kalmijn et al. 1997) found that individuals in The Netherlands who consumed more fish (a marker for polyunsaturated fatty acids including DHA) had a reduced risk of developing AD. There is also data from the Framingham cohort (Kyle et al. 1999) suggesting that a lower DHA level is a predictor of all-cause dementia, including AD. Terano et al. (1999) reported that DHA supplementation resulted in improvement in patients with moderately severe dementia on the basis of thrombotic cerebrovascular disease.

\section{Ginkgo}

Herbal extracts from Ginkgo biloba, are capable of scavenging free radicals, a property that is thought to be due, in part, to their flavonoid components (Bastianetto et al. $2000 \mathrm{~b}$ ). A ginkgo extract has been shown to be neuroprotective against $\beta$-amyloid toxicity (Bastianetto et al. $2000 a$ ). While ginkgo suffers from a relative lack of good clinical trials to support its use, it is perhaps one of the better-studied supplements taken for cognition. A metaanalysis by Oken et al. (1998) found only four studies of fifty evaluating its use in patients with $\mathrm{AD}$ that met adequate criteria for inclusion. The conclusion from this review was that patients with $\mathrm{AD}$ receiving ginkgo had a slight improvement in cognition. There was inconclusive evidence to determine the effect of ginkgo on non-cognitive behavioural measures, functional measures, or a clinician's global rating. Recently, Le Bars et al. (2000) published the results of a double-blind placebo-controlled parallel-group 26week, multicentre study comparing ginkgo $(40 \mathrm{mg}$ three times daily) with a placebo. The study included results for the subset of patients with mild to moderate $\mathrm{AD}$, with outcomes assessed by cognitive and global measures. There was an improvement of 1.7 points at 26 weeks in the cognitive component of the Alzheimer Disease Assessment Scale. This level of improvement is somewhat less than that seen with donepezil and other US Food and Drug Administration-approved cholinesterase inhibitors for AD, which generally demonstrate approximately a 3-point improvement on the same cognitive scale (Grundman \& Thal, 2000). Unlike the cholinesterase inhibitors that have been approved thus far, there was no significant effect seen in the clinical global impression of change, which means that the clinician evaluating the subjects could not detect a difference in the treated subjects. It appears that the doses of ginkgo used in that study were comparable with suboptimal therapeutic doses of currently-marketed cholinesterase inhibitors. On the other hand, ginkgo appears to be relatively free of side effects that can occur with some cholinesterase inhibitors. It is unknown if higher doses of ginkgo might be more effective. Additional clinical trials of ginkgo in patients with AD are underway.

\section{Huperzine A}

Huperzine $A$ is a reversible and selective acetylcholinesterase inhibitor (Cheng \& Tang, 1998; Wang \& Tang, 1998; Ye et al. 1999) derived from the Chinese club moss Huperzia serrata. Huperzine A and other cholinesterase inhibitors (e.g. donepezil and tacrine) were recently found to offer neuroprotection against $\beta$-amyloid toxicity, possibly through nicotinic receptor activation or induction of antioxidant enzymes (Svensson \& Nordberg, 1998; Xiao et al. $2000 \mathrm{~b}$ ). It is conceivable, therefore, that these neuroprotective properties may contribute to the clinical efficacy of cholinesterase inhibitors in the treatment of $\mathrm{AD}$. Huperzine can be purchased as a dietary supplement in pharmacies and health food stores. Two trials have been reported in patients with $\mathrm{AD}$, both in China. The first to be published (Xu et al. 1995) reported on an 8-week doubleblind placebo-controlled multicentre trial of Huperzine A tablets $(100 \mu \mathrm{g}$ twice daily in 103 subjects with $\mathrm{AD})$. The authors noted improvement in $58 \%$ of the treated patients $v$. $36 \%$ of the placebo group in areas including memory, cognition and behaviour. Comparison with studies typically conducted in Western countries, however, should be made with caution; for example, half the patients in this study had only an elementary school education or less. Also, the mean mini-mental status test score was only $14-16$, whereas in most studies used for regulatory approval in the USA the mean mini-mental status test scores tend to be about 20 . Approximately $10 \%$ of the patients had gastrointestinal side 
effects. The second, even shorter study (Zhang et al. 1991) claimed that Huperzine A was efficacious, even though the treatment period for senile and pre-senile memory disorders was only 2 weeks. Huperzine is an interesting compound that may well have some efficacy in AD, but it is difficult to draw firm conclusions based on the current data. Additional clinical trials with this agent are indicated.

\section{Curcumin}

Curcumin is an antioxidant derived from turmeric, the spice that provides curry with its yellow colour. Kim et al. (2001) found that curcumin was able to protect $\mathrm{PC} 12$ cells from $\beta$-amyloid toxicity. A recent report by Frautschy et al. (2000) found that curcumin could protect against behavioural deficits and lipid peroxidation induced by $\beta$-amyloid infusion in an animal model. Given these findings, further studies with curcumin in human subjects would be of interest.

\section{Ginseng}

Certain ginsenosides isolated from Panax spp. ginseng herb have been shown to reduce glutamate-induced neurotoxicity in neuronal cell cultures (Kim et al. 1998). In these experiments pretreatment with ginsenosides inhibited the overproduction of $\mathrm{NO}$ and malondialdehyde, and the influx of $\mathrm{Ca}$. No studies of ginseng in $\mathrm{AD}$ have yet been reported. Recently, Wesnes et al. (2000) published a study examining a ginseng-ginkgo combination given to healthy middleaged volunteers. A small improvement was seen in a memory index derived from a computerized battery in the active treatment group compared with controls. It is questionable, however, as to whether the subjects detected any benefit, as there was no improvement in a variety of other measures, including a number of subjective ratings of alertness, calmness, contentment, mood or well-being. Also, since the formulation studied was a combination of ginseng and ginkgo, it is difficult to draw any conclusions regarding the potential value of ginseng alone.

\section{Vinpocetine}

Vinpocetine is an alkaloid derived from Vinca spp. once favoured as a treatment for stroke (Bereczki \& Fekete, 1999; Gulyas et al. 1999), owing to its effects on cerebral blood flow and glucose utilization following ischaemia (Rischke \& Krieglstein, 1990). Vinpocetine has also been shown to be a free radical scavenger and to protect PC12 cells from $\beta$-amyloid toxicity. Findings of relatively short duration trials of this agent, both in healthy volunteers (Subhan \& Hindmarch, 1985) and in patients with varying dementing illnesses (Balestreri et al. 1987; Hindmarch et al. 1991), suggested some benefit in cognitive performance measures. A 1-year open-label study of an escalating dose of vinpocetine in fifteen subjects with $\mathrm{AD}$ by Thal et al. (1989), however, revealed a decline in all cognitive measures at the same rate as those of a matched control group. They concluded that vinpocetine was likely to be ineffective in improving cognitive deficits or slowing the progression of $\mathrm{AD}$.

\section{Other dietary and lifestyle strategies for prevention and treatment of Alzheimer's disease}

There is accumulating evidence that a diet high in fat and cholesterol may increase the risk of dementia and AD (Kalmijn et al. 1997; Notkola et al. 1998; Grant, 1999). In experimental animals a high-cholesterol diet is associated with increased deposition of brain $\beta$-amyloid. Rabbits fed high-fat high-cholesterol diets demonstrate increased $\beta$-amyloid in the brain (Sparks et al. 2000). Similarly, transgenic mice that produce $\beta$-amyloid produce even greater amounts of $\beta$-amyloid when fed a high-cholesterol diet (Refolo et al. 2000). Recently, the use of certain cholesterol-lowering agents (statins) has been associated with a reduced risk of dementia and $\mathrm{AD}$ in epidemiological studies (Wolozin et al. 1999; Jick et al. 2000). These agents have been shown to reduce intracellular and extracellular levels of $\beta$-amyloid in hippocampal neurons (Fassbender et al. 2001). Despite these promising findings it is likely that a diet low in fat and cholesterol may be most helpful during middle age. Several studies were unable to establish high cholesterol as a risk factor for AD in the years just before diagnosis (Notkola et al. 1998; Romas et al. 1999; Breteler, 2000). In fact, serum cholesterol may already be somewhat lower in the years just preceding and following diagnosis (Foy et al. 1999; Romas et al. 1999; Lerner et al. 2000). In contrast to a high-fat diet, a recent study (Engelhart et al. 2000) found that individuals who consumed more vegetables had a lower risk of dementia and AD.

In a prospective community study in the Bordeaux area of France, Orgogozo et al. (1997) found that moderate red wine drinking was associated with a lower incidence of AD at follow-up. This epidemiological study is supported by other experiments indicating that red wine constituents such as resveratrol can protect against NO toxicity in hippocampal neurons (Bastianetto et al. 2000c) and inhibit lipoprotein oxidation (Chopra et al. 2000).

Learning new things and maintaining a high level of intellectual activity throughout the lifespan, as well as exercising, may also reduce the risk of $\mathrm{AD}$ (Friedland et al. 2001), possibly by increasing synapses, initiating angiogenesis or by promoting neurogenesis (Black et al. 1990; Isaacs et al. 1992; Kempermann et al. 1997).

\section{Conclusions}

Recent clinical trials in $\mathrm{AD}$ have shown that we cannot rely on supportive basic science and epidemiological data to make clinical decisions regarding the use of putative agents in patients with $\mathrm{AD}$. Oestrogen has long been thought likely to be effective in $\mathrm{AD}$; however, recent clinical trials in patients with $A D$ have shown no benefit in this population (although their use for prevention of $\mathrm{AD}$ is still an open question). It was hoped that cyclooxygenase- 2 inhibitors might be neuroprotective in AD due to their anti-inflammatory effect. Thus far, however, they do not appear to be effective treatment in clinical trials. Acetylcarnitine and idebenone are yet additional examples of promising agents that have been disappointing in clinical trials. 
Combinations of vitamins, minerals and herbal antioxidants are likely to offer greater potential benefit for AD than any single antioxidant, especially if the agents work in different cellular compartments or have complementary mechanisms of action (e.g. vitamins E, C and ubiquinone). Nevertheless, it is not a simple matter to develop the ideal mixture of antioxidants for human use. While in theory this approach is appealing, by trying to deal with several sources of oxidative stress simultaneously, it is not so clear how to optimize the dose of each component or assure that when they are mixed they won't have an interacting toxicity or loss of efficacy. In a clinical trial of selegiline and vitamin $\mathrm{E}$ in $\mathrm{AD}$ the combination of selegiline and vitamin $\mathrm{E}$ was no better than each agent alone (Sano et al. 1997a). Preclinical safety studies in animals may be helpful for detecting likely toxicity, but extrapolating optimal dosing from current animal models and scaling that to man is challenging. Large-scale testing of many compounds in human subjects is also complicated, since reduction of oxidative damage is not a valid clinical outcome. Oxidative markers could be used, but it needs to be demonstrated that such surrogates correlate with clinical improvement. In the case of antioxidant trials attempting to prevent or delay $\mathrm{AD}$, antioxidant mixtures need to be administered to normal elderly subjects or individuals with mild cognitive impairment before they develop clinical AD. Given that only a minority of such individuals develop AD over the course of a few years, such trials will be time consuming and expensive. Despite these concerns, it seems we have little choice but to conduct such trials if we are to get beyond our current impasse and develop optimal antioxidant therapy for prevention and treatment of AD.

\section{Acknowledgements}

Support for this work was provided by grants from the National Institute on Aging (AG 10483 and AG 05131) and from the Institute for the Study of Aging.

\section{References}

Adams JD Jr, Klaidman LK, Odunze IN, Shen HC \& Miller CA (1991) Alzheimer's and Parkinson's disease. Brain levels of glutathione, glutathione disulfide, and vitamin E. Molecular and Chemical Neuropathology 14, 213-226.

Bachurin S, Oxenkrug G, Lermontova N, Afanasiev A, Beznosko B, Vankin G, Shevtzova E, Mukhina T \& Serkova T (1999) $\mathrm{N}$-acetylserotonin, melatonin and their derivatives improve cognition and protect against beta-amyloid-induced neurotoxicity. Annals of the New York Academy of Sciences 890 , $155-166$.

Balestreri R, Fontana L \& Astengo F (1987) A double-blind placebo controlled evaluation of the safety and efficacy of vinpocetine in the treatment of patients with chronic vascular senile cerebral dysfunction. Journal of the American Geriatrics Society 35, 425-430.

Bastianetto S, Ramassamy C, Dore S, Christen Y, Poirier J \& Quirion R (2000a) The Ginkgo biloba extract (EGb 761) protects hippocampal neurons against cell death induced by betaamyloid. European Journal of Neuroscience 12, 1882-1890.

Bastianetto S, Ramassamy C, Poirier J \& Quirion R (1999) Dehydroepiandrosterone (DHEA) protects hippocampal cells from oxidative stress-induced damage. Molecular Brain Research 66, 35-41.

Bastianetto S, Zheng WH \& Quirion R (2000b) The Ginkgo biloba extract (EGb 761) protects and rescues hippocampal cells against nitric oxide-induced toxicity: involvement of its flavonoid constituents and protein kinase C. Journal of Neurochemistry 74, $2268-2277$.

Bastianetto S, Zheng WH \& Quirion R (2000c) Neuroprotective abilities of resveratrol and other red wine constituents against nitric oxide-related toxicity in cultured hippocampal neurons. British Journal of Pharmacology 131, 711-720.

Beal MF \& Matthews RT (1997) Coenzyme Q10 in the central nervous system and its potential usefulness in the treatment of neurodegenerative diseases. Molecular Aspects of Medicine 18, Suppl, S169-S179.

Behl C, Davis J, Cole GM \& Schubert D (1992) Vitamin E protects nerve cells from amyloid beta protein toxicity. Biochemical and Biophysical Research Communications 186, 944-950.

Behl C, Davis JB, Lesley R \& Schubert D (1994) Hydrogen peroxide mediates amyloid beta protein toxicity. Cell 77, 817-827.

Behl C, Skutella T, Lezoualc'h F, Post A, Widmann M, Newton CJ \& Holsboer F (1997) Neuroprotection against oxidative stress by estrogens: structure-activity relationship. Molecular Pharmacology 51, 535-541.

Bereczki D \& Fekete I (1999) A systematic review of vinpocetine therapy in acute ischaemic stroke. European Journal of Clinical Pharmacology 55, 349-352.

Berr C, Balansard B, Arnaud J, Roussel AM \& Alpérovitch A (2000) Cognitive decline is associated with systemic oxidative stress: the EVA study. Etude du Vieillissement Artériel. Journal of the American Geriatrics Society 48, 1285-1291.

Black JE, Isaacs KR, Anderson BJ, Alcantara AA \& Greenough WT (1990) Learning causes synaptogenesis, whereas motor activity causes angiogenesis, in cerebellar cortex of adult rats. Proceedings of the National Academy of Sciences USA 87 , $5568-5572$.

Borek C (2001) Antioxidant health effects of aged garlic extract. Journal of Nutrition 131, 1010S-1015S.

Bourdel-Marchasson I, Delmas-Beauvieux MC, Peuchant E, Richard-Harston S, Decamps A, Reignier B, Emeriau JP \& Rainfray M (2001) Antioxidant defences and oxidative stress markers in erythrocytes and plasma from normally nourished elderly Alzheimer patients. Age and Ageing 30, 235-241.

Breteler MM (2000) Vascular risk factors for Alzheimer's disease: an epidemiologic perspective. Neurobiology of Aging 21, 153-160.

Brewer GJ \& Wallimann TW (2000) Protective effect of the energy precursor creatine against toxicity of glutamate and beta-amyloid in rat hippocampal neurons. Journal of Neurochemistry $\mathbf{7 4 ,}$ 1968-1978.

Brooks JO III, Yesavage JA, Carta A \& Bravi D (1998) Acetyl L-carnitine slows decline in younger patients with Alzheimer's disease: a reanalysis of a double-blind, placebo-controlled study using the trilinear approach. International Psychogeriatrics 10, 193-203.

Bush AI, Pettingell WH, Multhaup G, de Paradis M, Vonsattel JP, Gusella JF, Beyreuther K, Masters CL \& Tanzi RE (1994) Rapid induction of Alzheimer A beta amyloid formation by zinc. Science 265, 1464-1467.

Cheng DH \& Tang XC (1998) Comparative studies of huperzine A, E2020, and tacrine on behavior and cholinesterase activities. Pharmacology, Biochemistry and Behaviour 60, 377-386.

Chopra M, Fitzsimons PE, Strain JJ, Thurnham DI \& Howard AN (2000) Nonalcoholic red wine extract and quercetin inhibit LDL oxidation without affecting plasma antioxidant vitamin and carotenoid concentrations. Clinical Chemistry 46, 1162-1170. 
Chyan YJ, Poeggeler B, Omar RA, Chain DG, Frangione B, Ghiso J \& Pappolla MA (1999) Potent neuroprotective properties against the Alzheimer beta-amyloid by an endogenous melatonin-related indole structure, indole-3-propionic acid. Journal of Biological Chemistry 274, 21937-21942.

Cornett CR, Markesbery WR \& Ehmann WD (1998) Imbalances of trace elements related to oxidative damage in Alzheimer's disease brain. Neurotoxicology 19, 339-345.

Daniels WM, van Rensburg SJ, van Zyl JM \& Taljaard JJ (1998) Melatonin prevents beta-amyloid-induced lipid peroxidation. Journal of Pineal Research 24, 78-82.

de Bustos F, Molina JA, Jimenez-Jimenez FJ, Garcia-Redondo A, Gomez-Escalonilla C, Porpa-Etessam J et al. (2000) Serum levels of coenzyme Q10 in patients with Alzheimer's disease. Journal of Neural Transmission 107, 233-239.

Dechent P, Pouwels PJ, Wilken B, Hanefeld F \& Frahm J (1999) Increase of total creatine in human brain after oral supplementation of creatine-monohydrate. American Journal of Physiology 277, R698-R704.

Deibel MA, Ehmann WD \& Markesbery WR (1996) Copper, iron, and zinc imbalances in severely degenerated brain regions in Alzheimer's disease: possible relation to oxidative stress. Journal of the Neurological Sciences 143, 137-142.

Engelhart MJ Ruitenberg A, Swieten JC, Witteman JCM, Hofman A \& Breteler MB (2000) Dietary antioxidants and the risk of dementia. The Rotterdam study. Neurobiology of Aging 21, 203 S.

Fagarasan MO \& Aisen PS (1996) IL-1 and anti-inflammatory drugs modulate A beta cytotoxicity in PC12 cells. Brain Research 723, 231-234.

Fagarasan MO \& Efthimiopoulos S (1996) Mechanism of amyloid beta-peptide (1-42) toxicity in PC12 cells. Molecular Psychiatry $1,398-403$.

Fassbender K, Simons M, Bergmann C, Stroick M, Lutjohann D, Keller $\mathrm{P}$ et al. (2001) Simvastatin strongly reduces levels of Alzheimer's disease beta-amyloid peptides Abeta 42 and Abeta 40 in vitro and in vivo. Proceedings of the National Academy of Sciences USA 10, 10

Foy CJ, Passmore AP, Vahidassr MD, Young IS \& Lawson JT (1999) Plasma chain-breaking antioxidants in Alzheimer's disease, vascular dementia and Parkinson's disease. Quarterly Journal of Medicine 92, 39-45.

Frautschy SA, Harris-White ME, Miller SA, Kim P, Jimenez I, Csizar E et al. (2000) Prevention of $A \beta$ amyloid peptide infusion-induced behavioral deficits, neuroinflammation and neurodegeneration by dietary anti-inflammatory/antioxidant supplements. Society for Neuroscience 26, 1830.

Friedland RP, Fritsch T, Smyth K, Koss E, Lerner AJ, Chen CH, Petot GJ \& Debanne SM (2001) Patients with Alzheimer's disease have reduced activities in midlife compared with healthy control-group members. Proceedings of the National Acaderny of Sciences USA 98, 3440-3445.

Gabuzda D, Busciglio J, Chen LB, Matsudaira P \& Yankner BA (1994) Inhibition of energy metabolism alters the processing of amyloid precursor protein and induces a potentially amyloidogenic derivative. Journal of Biological Chemistry 269, 13623-13628.

Gonzalez C, Martin T, Cacho J, Brenas MT, Arroyo T, GarciaBerrocal B, Navajo JA \& Gonzalez-Buitrago (1999) Serum zinc, copper, insulin and lipids in Alzheimer's disease epsilon 4 apolipoprotein E allele carriers. European Journal of Clinical Investigation 29, 637-642.

Good PF, Werner P, Hsu A, Olanow CW \& Perl DP (1996) Evidence of neuronal oxidative damage in Alzheimer's disease. American Journal of Pathology 149, 21-28.

Grant W (1999) Dietary links to Alzheimer's disease: 1999 update. Journal of Alzheimer's Disease 1, 197-201.
Grundman M (2000) Vitamin E and Alzheimer disease: the basis for additional clinical trials. American Journal of Clinical Nutrition 71, 630S-636S.

Grundman M \& Thal TJ (2000) Treatment of Alzheimer's disease: rationale and strategies. Neurologic Clinics 18 , 807-828.

Guevara J, Espinosa B, Zenteno E, Vazguez I, Luna J, Perry G \& Mena R (1998) Altered glycosylation pattern of proteins in Alzheimer disease. Journal of Neuropathology and Experimental Neurology 57, 905-914.

Gulyas B, Halldin C, Karlsson P, Chou YH, Swahn CG, Bonock P, Paroczai M \& Farde L (1999) Brain uptake and plasma metabolism of [11C]vinpocetine: a preliminary PET study in a cynomolgus monkey. Journal of Neuroimaging 9, 217-222.

Hager K, Marahrens A, Kenklies M, Riederer P \& Munch G (2001) Alpha-lipoic acid as a new treatment option for Alzheimer type dementia. Archives of Gerontology and Geriatrics 32, 275-282.

Hindmarch I, Fuchs HH \& Erzigkeit H (1991) Efficacy and tolerance of vinpocetine in ambulant patients suffering from mild to moderate organic psychosyndromes. International Clinical Psychopharmacology 6, 31-43.

Hirai K, Hayako H, Kato K \& Miyamoto M (1998) Idebenone protects hippocampal neurons against amyloid beta-peptideinduced neurotoxicity in rat primary cultures. Naunyn Schmiedeburgs Archives of Pharmacology 358, 582-585.

Hossain MS, Hashimoto M, Gamoh S \& Masumura S (1999) Antioxidative effects of docosahexaenoic acid in the cerebrum versus cerebellum and brainstem of aged hypercholesterolemic rats. Journal of Neurochemistry 72, 1133-1138.

Huang X, Cuajungco MP, Atwood CS, Moir RD, Tanzi RE \& Bush AI (2000) Alzheimer's disease, beta-amyloid protein and zinc. Journal of Nutrition 130, 1488S-1492S.

Isaacs KR, Anderson BJ, Alcantara AA, Black JE \& Greenough WT (1992) Exercise and the brain: angiogenesis in the adult rat cerebellum after vigorous physical activity and motor skill learning. Journal of Cerebral Blood Flow and Metabolism 12, $110-119$.

Jama JW, Launer LJ, Witteman JC, den Breeijen JH, Breteler MM, Grobbee DE \& Hofman A (1996) Dietary antioxidants and cognitive function in a population-based sample of older persons. The Rotterdam Study. American Journal of Epidemiology 144, 275-280.

Jeandel C, Nicolas MB, Dubois F, Nabet-Belleville F, Penin F \& Cuny $\mathrm{G}$ (1989) Lipid peroxidation and free radical scavengers in Alzheimer's disease. Gerontology 35, 275-282.

Jeyarajah DR, Kielar M, Penfield J \& Lu CY (1999) Docosahexaenoic acid, a component of fish oil, inhibits nitric oxide production in vitro. Journal of Surgical Research 83, 147-150.

Jick H, Zornberg GL, Jick SS, Seshadri S \& Drachman DA (2000) Statins and the risk of dementia. Lancet 356, 1627-1631.

Jimenez-Jimenez FJ, de Bustos F, Gasalla T \& Orti-Pareja M (1996) Estres oxidativo y sistema nervioso central (oxidative stress in the central nervous system). Neurologia 11, 13-22.

Jimenez-Jimenez FJ, de Bustos F, Molina JA, Benito-Leon J, Tallon-Barranco A, Gasalla T, Orti-Pareja M, Guillaman F, Rubio JC, Arenas J \& Enriquez-de-Salamanca R (1997) Cerebrospinal fluid levels of alpha-tocopherol (vitamin E) in Alzheimer's disease. Journal of Neural Transmission 104, 703-710.

Kalmijn S, Launer LJ, Ott A, Witteman JC, Hofman A \& Breteler MM (1997) Dietary fat intake and the risk of incident dementia in the Rotterdam Study. Annals of Neurology 42, 776-782.

Kempermann G, Kuhn HG \& Gage FH (1997) More hippocampal neurons in adult mice living in an enriched environment. Nature 386, 493-495.

Kihara T, Shimohama S, Sawada H, Kimura J, Kume T, Kochiyama H, Maeda T \& Akaike A (1997) Nicotinic receptor 
stimulation protects neurons against beta-amyloid toxicity. Annals of Neurology 42, 159-163.

Kim DS, Park SY \& Kim JK (2001) Curcuminoids from Curcuma longa L. (Zingiberaceae) that protect PC12 rat pheochromocytoma and normal human umbilical vein endothelial cells from betaA (1-42) insult. Neuroscience Letters 303, 57-61.

Kim YC, Kim SR, Markelonis GJ \& Oh TH (1998) Ginsenosides $\mathrm{Rb} 1$ and $\mathrm{Rg} 3$ protect cultured rat cortical cells from glutamate-induced neurodegeneration. Journal of Neuroscience Research 53, 426-432.

Kyle DJ, Schaefer E, Patton G \& Beiser A (1999) Low serum docosahexaenoic acid is a significant risk factor for Alzheimer's dementia. Lipids 34, S245.

La Rue A, Koehler KM, Wayne SJ, Chiulli SJ, Haaland KY \& Garry PJ (1997) Nutritional status and cognitive functioning in a normally aging sample: a 6-y reassessment. American Journal of Clinical Nutrition 65, 20-29.

Le Bars PL, Kieser M \& Itil KZ (2000) A 26-week analysis of a double-blind, placebo-controlled trial of the ginkgo biloba extract EGb 761 in dementia. Dementia Geriatrics and Cognitive Disorders 11, 230-237.

Lerner AJ, Mizrahi EH, Chen CH, Eckman C, Younkin S \& Siavalas EL et al. (2000) Relationship of plasma amyloid beta fragments to serum cholesterol, high density lipoprotein, albumin, and apolipoprotein E genotype. Neurology 54, A366.

Liu F, Lau BH, Peng Q \& Shah V (2000) Pycnogenol protects vascular endothelial cells from beta-amyloid-induced injury. Biological and Pharmaceutical Bulletin 23, 735-737.

Lovell MA, Ehmann WD, Butler SM \& Markesbery WR (1995) Elevated thiobarbituric acid-reactive substances and antioxidant enzyme activity in the brain in Alzheimer's disease. Neurology 45, 1594-1601.

Lovell MA, Gabbita SP \& Markesbery WR (1999a) Increased DNA oxidation and decreased levels of repair products in Alzheimer's disease ventricular CSF. Journal of Neurochemistry 72, 771-776.

Lovell MA, Xie C \& Markesbery WR (1999b) Protection against amyloid beta peptide toxicity by zinc. Brain Research 823, 88-95.

Maes M, DeVos N, Wauters A, Demedts P, Maurits VW, Neels H et al. (1999) Inflammatory markers in younger vs elderly normal volunteers and in patients with Alzheimer's disease. Journal of Psychiatric Research 33, 397-405.

Marcus DL, Thomas C, Rodriguez C, Simberkoff K, Tsai JS, Strafaci JA \& Freedman ML (1998) Increased peroxidation and reduced antioxidant enzyme activity in Alzheimer's disease. Experimental Neurology 150, 40-44.

Mark RJ, Keller JN, Kruman I \& Mattson MP (1997) Basic FGF attenuates amyloid beta-peptide-induced oxidative stress, mitochondrial dysfunction, and impairment of $\mathrm{Na}+/ \mathrm{K}+-\mathrm{ATPase}$ activity in hippocampal neurons. Brain Research 756, 205-214.

Markesbery WR \& Lovell MA (1998) Four-hydroxynonenal, a product of lipid peroxidation, is increased in the brain in Alzheimer's disease. Neurobiology of Aging 19, 33-36.

Masaki KH, Losonczy KG, Izmirlian G, Foley DJ, Ross GW, Petrovitch H, Havlik R \& White LR (2000) Association of vitamin $E$ and $C$ supplement use with cognitive function and dementia in elderly men. Neurology 54, 1265-1272.

Mecocci P, MacGarvey U \& Beal MF (1994) Oxidative damage to mitochondrial DNA is increased in Alzheimer's disease. Annals of Neurology 36, 747-751.

Meseguer I, Molina JA, Jimenez-Jimenez FJ, Aguilar MV, Mateo-Vega CJ, Gonzalez-Munoz MJ et al. (1999) Cerebrospinal fluid levels of selenium in patients with Alzheimer's disease. Journal of Neural Transmission 106, 309-315.
Metcalfe T, Bowen DM \& Muller DP (1989) Vitamin E concentrations in human brain of patients with Alzheimer's disease, fetuses with Down's syndrome, centenarians, and controls. Neurochemical Research 14, 1209-1212.

Misonou H, Morishima-Kawashima M \& Ihara Y (2000) Oxidative stress induces intracellular accumulation of amyloid beta-protein (Abeta) in human neuroblastoma cells. Biochemistry 39, 6951-6959.

Molina JA, Jimenez-Jimenez FJ, Aguilar MV, Meseguer I, MateosVega CJ, Gonzalez-Munoz MJ et al. (1998) Cerebrospinal fluid levels of transition metals in patients with Alzheimer's disease. Journal of Neural Transmission 105, 479-488.

Moreira P, Pereira C, Santos MS \& Oliveira C (2000) Effect of zinc ions on the cytotoxicity induced by the amyloid beta-peptide. Antioxidant Redox Signal 2, 317-325.

Morris MC, Evans DA, Bienias JL, Wilson RS \& Tangney CC, (2000) Dietary intake of vitamin $\mathrm{C}$ and vitamin $\mathrm{E}$ and cognitive decline in a biracial community programme. Neurobiology of Aging 21, S202.

Morris MC, Beckett LA, Scherr PA, Hebert LE, Bennett DA, Field TS \& Evans DA (1998) Vitamin E and vitamin C supplement use and risk of incident Alzheimer disease. Alzheimer Disease and Associated Disorders 12, 121-126.

Mullaart E, Boerrigter ME, Ravid R, Swaab DF \& Vijg J (1990) Increased levels of DNA breaks in cerebral cortex of Alzheimer's disease patients. Neurobiology of Aging 11, 169-173.

Muller WE, Romero FJ, Perovic S, Pergande G \& Pialoglou P (1997) Protection of flupirtine on beta-amyloid-induced apoptosis in neuronal cells in vitro: prevention of amyloidinduced glutathione depletion. Journal of Neurochemistry 68 2371-2377.

Notkola IL, Sulkava R, Pekkanen J, Erkinjuntti T, Ehnholm C, Kivinen P, Tuomilehto J \& Nissinen A (1998) Serum total cholesterol, apolipoprotein E epsilon 4 allele, and Alzheimer's disease. Neuroepidemiology 17, 14-20.

Nourooz-Zadeh J, Liu EH, Yhlen B, Anggard EE \& Halliwell B (1999) F4-isoprostanes as specific marker of docosahexaenoic acid peroxidation in Alzheimer's disease. Journal of Neurochemistry 72, 734-740.

Nunomura A, Perry G, Pappolla MA, Wade R, Hirai K, Chiba S \& Smith MA (1999) RNA oxidation is a prominent feature of vulnerable neurons in Alzheimer's disease. Journal of Neuroscience 19, 1959-1964.

Oken BS, Storzbach DM \& Kaye JA (1998) The efficacy of Ginkgo biloba on cognitive function in Alzheimer disease. Archives of Neurology 55, 1409-1415.

Olivieri G, Baysang G, Meier F, Muller-Spahn F, Stahelin HB, Brockhaus M \& Brack C (2001) N-acetyl-L-cysteine protects SHSY5Y neuroblastoma cells from oxidative stress and cell cytotoxicity: effects on beta-amyloid secretion and tau phosphorylation. Journal of Neurochemistry 76, 224-233.

Orgogozo JM, Dartigues JF, Lafont S, Letenneur L, Commenges D, Salamon R, Renaud S \& Breteler MB (1997) Wine consumption and dementia in the elderly: a prospective community study in the Bordeaux area. Revue Neurologique 153, 185-192.

Packer L, Tritschler HJ \& Wessel K (1997) Neuroprotection by the metabolic antioxidant alpha-lipoic acid. Free Radical Biology and Medicine 22, 359-378.

Paleologos M, Cumming RG \& Lazarus R (1998) Cohort study of vitamin $C$ intake and cognitive impairment. American Journal of Epidemiology 148, 45-50.

Pappolla MA, Sos M, Omar RA, Bick RJ, Hickson-Bick DL, Reiter RJ, Efthimiopoulos S \& Robakis NK (1997) Melatonin prevents death of neuroblastoma cells exposed to the Alzheimer amyloid peptide. Journal of Neuroscience 17, 1683-1690. 
Pereira C, Agostinho P \& Oliveira CR (2000) Vinpocetine attenuates the metabolic dysfunction induced by amyloid betapeptides in PC12 cells. Free Radical Research 33, 497-506.

Pereira C, Santos MS \& Oliveira C (1999) Involvement of oxidative stress on the impairment of energy metabolism induced by A beta peptides on $\mathrm{PC} 12$ cells: protection by antioxidants. Neurobiology of Disease 6, 209-219.

Perkins AJ, Hendrie HC, Callahan CM, Gao S, Unverzagt FW, Xu Y, Hall KS \& Hui SL (1999) Association of antioxidants with memory in a multiethnic elderly sample using the Third National Health and Nutrition Examination Survey. American Journal of Epidemiology 150, 37-44.

Perrig WJ, Perrig P \& Stahelin HB (1997) The relation between antioxidants and memory performance in the old and very old. Journal of the American Geriatrics Society 45, 718-724.

Pfefferbaum A, Adalsteinsson E, Spielman D, Sullivan EV \& Lim $\mathrm{KO}$ (1999) In vivo brain concentrations of $\mathrm{N}$-acetyl compounds, creatine, and choline in Alzheimer disease. Archives of General Psychiatry 56, 185-192.

Prasad MR, Lovell MA, Yatin M, Dhillon H \& Markesbery WR (1998) Regional membrane phospholipid alterations in Alzheimer's disease. Neurochemical Research 23, 81-88.

Pratico D, Clark CM, Lee VM, Trojanowski JQ, Rokach J \& FitzGerald GA (2000) Increased 8, 12-iso-iPF2alpha-VI in Alzheimer's disease: correlation of a noninvasive index of lipid peroxidation with disease severity. Annals of Neurology $\mathbf{4 8}$, 809-812.

Pratico D \& Delanty N (2000) Oxidative injury in diseases of the central nervous system: focus on Alzheimer's disease. American Journal of Medicine 109, 577-585.

Refolo LM, Pappolla MA, Malester B, LaFrancois J, BryantThomas T, Wang R, Tint GS, Sambanurti K \& Duff K (2000) Hypercholesterolemia accelerates the Alzheimer's amyloid pathology in a transgenic mouse model. Neurobiology of Disease 7, 321-331.

Rischke R \& Krieglstein J (1990) Effects of vinpocetine on local cerebral blood flow and glucose utilization seven days after forebrain ischemia in the rat. Pharmacology 41, 153-160.

Riviere S, Birlouez-Aragon I, Nourhashemi F \& Vellas B (1998) Low plasma vitamin $\mathrm{C}$ in Alzheimer patients despite an adequate diet. International Journal of Geriatric Psychiatry 13 , 749-754.

Romas SN, Tang MX, Berglund L \& Mayeux R (1999) APOE genotype, plasma lipids, lipoproteins, and $\mathrm{AD}$ in community elderly. Neurology 53, 517-521.

Roth A, Schaffner W \& Hertel C (1999) Phytoestrogen kaempferol (3,4',5,7-tetrahydroxyflavone) protects $\mathrm{PC} 12$ and T47D cells from beta-amyloid-induced toxicity. Journal of Neuroscience Research 57, 399-404.

Rottkamp CA, Nunomura A, Raina AK, Sayre LM, Perry G \& Smith MA (2000) Oxidative stress, antioxidants, and Alzheimer disease. Alzheimer Disease and Associated Disorders 14, S62-S66.

Rottkamp CA, Raina AK, Zhu X, Gaier E, Bush AI, Attwood CS, Chevion M, Perry G \& Smith MA (2001) Redox-active iron mediates amyloid-beta toxicity. Free Radical Biology and Medicine 30, 447-450.

Samudralwar DL, Diprete CC, Ni BF, Ehmann WD \& Markesbery WR (1995) Elemental imbalances in the olfactory pathway in Alzheimer's disease. Journal of the Neurological Sciences $\mathbf{1 3 0}$, 139-145.

Sano M, Ernesto C, Thomas RG, Klauber MR, Schafer K, Grundman M et al. (1997a) A controlled trial of selegiline, alpha-tocopherol, or both as treatment for Alzheimer's disease. The Alzheimer's Disease Cooperative Study. New England Journal of Medicine 336, 1216-1222.
Sano M, Thomas RG \& Thal LJ (1997b) Alpha-tocopherol and Alzheimer's disease. New England Journal of Medicine 337, 573.

Schippling S, Kontush A, Arlt S, Buhmann C, Sturenburg HJ, Mann U, Muller-Thomsen T \& Beisiegel U (2000) Increased lipoprotein oxidation in Alzheimer's disease. Free Radical Biology and Medicine 28, 351-360.

Schmidt R, Hayn M, Reinhart B, Roob G, Schmidt H, Schumacher M, Watzinger N \& Launer LJ (1998) Plasma antioxidants and cognitive performance in middle-aged and older adults: results of the Austrian Stroke Prevention Study. Joumal of the American Geriatrics Society 46, 1407-1410.

Sinclair AJ, Bayer AJ, Johnston J, Warner C \& Maxwell SR (1998) Altered plasma antioxidant status in subjects with Alzheimer's disease and vascular dementia. International Journal of Geriatric Psychiatry 13, 840-845.

Smith MA, Perry G, Richey PL, Sayre LM, Anderson VE, Beal MF \& Kowall N (1996) Oxidative damage in Alzheimer"s. Nature 382, 120-121.

Smith MA, Richey Harris PL, Sayre LM, Beckman JS \& Perry G (1997) Widespread peroxynitrite-mediated damage in Alzheimer's disease. Journal of Neuroscience 17, 2653-2657.

Smith MA, Rottkamp CA, Nunomura A, Raina AK \& Perry G (2000) Oxidative stress in Alzheimer's disease. Biochimica et Biophysica Acta 1502, 139-144.

Soderberg M, Edlund C, Alafuzoff I, Kristensson K \& Dallner G (1992) Lipid composition in different regions of the brain in Alzheimer's disease/senile dementia of Alzheimer's type. Journal of Neurochemistry 59, 1646-1653.

Soderberg M, Edlund C, Kristensson K \& Dallner G (1991) Fatty acid composition of brain phospholipids in aging and in Alzheimer's disease. Lipids 26, 421-425.

Sparks DL, Martin TA, Gross DR \& Hunsaker JC 3rd (2000) Link between heart disease, cholesterol, and Alzheimer's disease: a review. Microscopy Research and Technique 50, 287-290.

Subhan Z \& Hindmarch I (1985) Psychopharmacological effects of vinpocetine in normal healthy volunteers. European Journal of Clinical Pharmacology 28, 567-571.

Subramaniam R, Koppal T, Green M, Yatin S, Jordan B, Drake J \& Butterfield DA (1998) The free radical antioxidant vitamin E protects cortical synaptosomal membranes from amyloid betapeptide(25-35) toxicity but not from hydroxynonenal toxicity: relevance to the free radical hypothesis of Alzheimer's disease. Neurochemical Research 23, 1403-1410.

Suh SW, Jensen KB, Jensen MS, Silva DS, Kesslak PJ, Danscher G \& Frederickson CJ (2000) Histochemically-reactive zinc in amyloid plaques, angiopathy, and degenerating neurons of Alzheimer's diseased brains. Brain Research 852, 274-278.

Svensson AL \& Nordberg A (1998) Tacrine and donepezil attenuate the neurotoxic effect of A beta(25-35) in rat PC12 cells. Neuroreport 9, 1519-1522.

Tarnopolsky MA \& Beal MF (2001) Potential for creatine and other therapies targeting cellular energy dysfunction in neurological disorders. Annals of Neurology 49, 561-574.

Terano T, Fujishiro S, Ban T, Yamamoto K, Tanaka T, Noguchi Y, Tamura Y, Yazawa K \& Hirayama T (1999) Docosahexaenoic acid supplementation improves the moderately severe dementia from thrombotic cerebrovascular diseases. Lipids $\mathbf{3 4}$, S345-S346.

Thal LJ, Calvani M, Amato A \& Carta A (2000) A 1-year controlled trial of acetyl-1-carnitine in early-onset AD. Neurology $\mathbf{5 5}$, 805-810.

Thal LJ, Carta A, Clarke WR, Ferris SH, Friedland RP, Petersen RC et al. (1996) A 1-year multicenter placebo-controlled study of acetyl-L-carnitine in patients with Alzheimer's disease. Neurology 47, 705-711. 
Thal LJ, Salmon DP, Lasker B, Bower D \& Klauber MR (1989) The safety and lack of efficacy of vinpocetine in Alzheimer's disease. Journal of the American Geriatrics Society 37, 515-520.

Vitek MP, Bhattacharya K, Glendening JM, Stopa E, Vlassara H, Bucala R, Manogue K \& Cerami A (1994) Advanced glycation end products contribute to amyloidosis in Alzheimer disease. Proceedings of the National Academy of Sciences USA 91, 4766-4770.

Wang T \& Tang XC (1998) Reversal of scopolamine-induced deficits in radial maze performance by (-)-huperzine A: comparison with E2020 and tacrine. European Journal of Pharmacology 349, 137-142.

Wei H, Leeds PR, Qian Y, Wei W, Chen R \& Chuang D (2000) Beta-amyloid peptide-induced death of PC 12 cells and cerebellar granule cell neurons is inhibited by long-term lithium treatment. European Journal of Pharmacology 392, 117-123.

Wesnes KA, Ward T, McGinty A \& Petrini O (2000) The memory enhancing effects of a Ginkgo biloba/Panax ginseng combination in healthy middle-aged volunteers. Psychopharmacology (Berlin) 152, 353-361.

Wolozin B, Kellman W, Celesia G \& Siegel G (1999) Decreased prevalence of Alzheimer's disease associated with HMG-CoA reductase inhibitors. Journal of the Neurological Sciences 25, 16 (13.9).

Xiao QX, Wang R, Han YF \& Tang XC (2000a) Protective effects of hyperzine $A$ on beta-amyloid $25-35$ induced oxidative injury in rat pheochromocytoma cells. Neuroscience Letters 286, 155-158.

Xiao QX, Wang R \& Tang XC (2000b) Huperzine A and tacrine attenuate beta-amyloid peptide-induced oxidative injury. Journal of Neuroscience Research 61, 564-569.

Xu SS, Gao ZX, Weng Z, Du ZM, Xu WA, Yang JS, Zhang ML, Tong ZH, Fang YS \& Chai XS (1995) Efficacy of tablet huperzine-A on memory, cognition, and behavior in Alzheimer's disease. Chung Kuo Yao Li Hsueh Pao 16, 391-395.

Yallampalli S, Micci MA \& Taglialatela G (1998) Ascorbic acid prevents beta-amyloid-induced intracellular calcium increase and cell death in PC12 cells. Neuroscience Letters 251, 105-108.
Yan JJ, Cho JY, Kim HS, Kim KL, Jung JS, Huh SO, Suh HW, Kim YH \& Song DK (2001) Protection against beta-amyloid peptide toxicity in vivo with long-term administration of ferulic acid British Journal of Pharmacology 133, 89-96.

Yan SD, Chen X, Schmidt AM, Brett J, Godman G, Zou YS, Scott CW, Caputo C, Frappier T \& Smith MA (1994) Glycated tau protein in Alzheimer disease: a mechanism for induction of oxidant stress. Proceedings of the National Academy of Sciences USA 91, 7787-7791.

Yao Z, Drieu K \& Papadopoulos V (2001) The Ginkgo biloba extract EGb 761 rescues the PC12 neuronal cells from betaamyloid-induced cell death by inhibiting the formation of betaamyloid-derived diffusible neurotoxic ligands. Brain Research 889, 181-190.

Yatin SM, Yatin M, Aulick T, Ain KB \& Butterfield DA (1999) Alzheimer's amyloid $\beta$-peptide associated free radicals increase rat embryonic neuronal polyamine uptake and ornithine decarboxylase activity: protective effect of vitamin $E$. Neuroscience Letters 263, 17-20.

Ye JW, Cai JX, Wang LM \& Tang XC (1999) Improving effects of huperzine $\mathrm{A}$ on spatial working memory in aged monkeys and young adult monkeys with experimental cognitive impairment. Journal of Pharmacology and Experimental Therapeutics 288, 814-819.

Zaman Z, Roche S, Fielden P, Frost PG, Niriella DC \& Cayley AC (1992) Plasma concentrations of vitamins $A$ and $E$ and carotenoids in Alzheimer's disease. Age and Ageing 21, 91-94.

Zhang RW, Tang XC, Han YY, Sang GW, Zhang YD, Ma YX, Zhang CL \& Yang RM (1991) Drug evaluation of huperzine A in the treatment of senile memory disorders. Chung Kuo Yao $\mathrm{Li}$ Hsueh Pao 12, 250-252.

Zhou Y, Gopalakrishnan V \& Richardson JS (1996) Actions of neurotoxic beta-amyloid on calcium homeostasis and viability of PC12 cells are blocked by antioxidants but not by calcium channel antagonists. Journal of Neurochemistry 67, 1419-1425.

Zhou Y \& Richardson JS (1996) Cholesterol protects PC12 cells from beta-amyloid induced calcium disordering and cytotoxicity. Neuroreport 7, 2487-2490. 